\title{
OXIDOPOLYBORATE ANIONS TEMPLATED BY TRANSITION-METAL COMPLEX CATIONS: SELF-ASSEMBLED SYNTHESES AND STRUCTURAL STUDIES (XRD) OF $\left[\mathrm{Co}\left(\mathrm{NH}_{3}\right)_{6}\right]_{2}\left[\mathrm{~B}_{4} \mathrm{O}_{5}(\mathrm{OH})_{4}\right]_{3} \cdot 11 \mathrm{H}_{2} \mathrm{O}$, $\left[\mathrm{Ni}(\mathrm{phen})_{3}\right]\left[\mathrm{B}_{7} \mathrm{O}_{9}(\mathrm{OH})_{5}\right] \cdot 9.5 \mathrm{H}_{2} \mathrm{O}$ and $\left[\mathrm{Zn}(\mathrm{dac})_{2}\left(\mathrm{H}_{2} \mathrm{O}\right)_{2}\right]\left[\mathrm{B}_{7} \mathrm{O}_{9}(\mathrm{OH})_{5}\right] \cdot \mathrm{H}_{2} \mathrm{O}$
}

\author{
Mohammed A. Altahan ${ }^{1 \#}$, Michael A. Beckett ${ }^{1 *}$, Simon J. Coles ${ }^{2}$, Peter N. Horton ${ }^{2}$ \\ ${ }^{1}$ School of Natural Sciences, Bangor University,LL57 2UW, UK \\ ${ }^{2}$ Chemistry, University of Southampton, Southampton, SO17 1BJ, UK \\ ${ }^{*}$ Current address: Chemistry Department, College of Science, University of Thi-Qar, Nasiriyah, Iraq. \\ *m.a.beckett@bangor.ac.uk
}

\begin{abstract}
The new oxidopolyborate salts $\left[\mathrm{Co}\left(\mathrm{NH}_{3}\right)_{6}\right]_{2}\left[\mathrm{~B}_{4} \mathrm{O}_{5}(\mathrm{OH})_{4}\right]_{3} \cdot 11 \mathrm{H}_{2} \mathrm{O}(\mathbf{1})$, $\left[\mathrm{Ni}(\text { phen })_{3}\right]\left[\mathrm{B}_{7} \mathrm{O}_{9}(\mathrm{OH})_{5}\right] \cdot 9.5 \mathrm{H}_{2} \mathrm{O}$ (2), and $\left[\mathrm{Zn}(\mathrm{dac})_{2}\left(\mathrm{H}_{2} \mathrm{O}\right)_{2}\right]\left[\mathrm{B}_{7} \mathrm{O}_{9}(\mathrm{OH})_{5}\right] \cdot \mathrm{H}_{2} \mathrm{O}$ (3), were crystallized, in moderate yields, from aqueous solutions containing $\mathrm{B}(\mathrm{OH})_{3}$ and the hydroxide salt of the corresponding cationic metal complex (prepared in situ) in moderate yields. Complexes 1-3, characterized by spectroscopic (NMR, IR) and thermal (TGA) methods and by single-crystal XRD studies, were obtained through cation-templated self-assembly reactions. Compound 1 contains insular tetraborate(2-) anions (4-1:2 $\Delta+2 T)$ and 2 and 3 both contain insular heptaborate(2-) anions (' $\mathrm{O}^{+}$' isomer, 6:(3A + 3T) + $\Delta$ ). The X-ray structures show that in all three compounds the polyborate anions are H-bonded together into extended networks, and there are multiple cation-anion H-bond interactions present in $\mathbf{1}$ and $\mathbf{3}$. Compound $\mathbf{2}$ has cation-cation $\pi$-stacking interactions. These interactions are likely to be responsible for templating the observed structures. Thermal decomposition of 1-3 in air yielded amorphous anhydrous borates of composition $\mathrm{CoB}_{6} \mathrm{O}_{10.5}, \mathrm{NiB}_{7} \mathrm{O}_{11.5}$ and $\mathrm{ZnB}_{7} \mathrm{O}_{11.5}$, respectively.
\end{abstract}

Key Words: Heptaborate(2-); Oxidoborate; Tetraborate(2-); Transition-metal complex; XRD study.

\section{INTRODUCTION}

Oxidopolyborate (borate) anions are a well-known class of compounds with many synthetic materials adding to the several hundred known naturally occurring minerals [1-4]. Many of these compounds have been structurally characterised by XRD studies and their structures range from simple partially condensed insular isolated anions through to fully condensed anhydrous complex 3-D networks [5-10]. In all structures, with the exceptions of rare borate anions derived from boron suboxides, the boron centres are in either 4-coordinate (tetrahedral) or 3-coordinate (trigonal planar) environments and are bound solely to oxygen atoms with a negative charge associated with each 4-coordinate boron centre. Non boron-bridging oxygen atoms normally exist as hydroxyl groups in isolated structures whereas $\mathrm{O}^{-}$ groups are not uncommon in the more condensed networks. Cations play an important role in stabilizing 
such structures though solid-state interactions with the anions [1-10]. Borates are important industrially and are used in many vitreous, agricultural, biostatic, and fire retardant applications [11,12]. In aqueous solution $\mathrm{B}(\mathrm{OH})_{3}$ exists as a complex mixture of interconverting polyborate anions $[14,15]$ and as such constitute a Dynamic Combinatorial Library (DCL) [13]. Addition of cations to this DCL of polyborate anions facilitates self-assembly and crystallization of specific polyborate salts. Frequently, pentaborate(1-) salts are formed [16-19], and we have engaged in a research programme to investigate why this is so and have used this knowledge to encourage, by choice of preferred cations, the crystal engineering of non-pentaborate(1-) compounds [20,21]. This research has led us to believe that cation/anion H-bonding, cationic charge, and steric effects all play important roles in this self-assembly process $[19,22]$. In this manuscript we investigate the reactions of $\left[\mathrm{Co}\left(\mathrm{NH}_{3}\right)_{6}\right]^{3+}$ (a highly-charged and potentially multi-H-bond donor cation) and $\left[\mathrm{Ni}(\mathrm{phen})_{3}\right]^{2+}$ (phen $=1,10$-phenanthroline) and $\left[\mathrm{Zn}(\mathrm{dac})_{2}\left(\mathrm{H}_{2} \mathrm{O}\right)_{2}\right]^{2+}$ (dac $=1$,2-diaminocyclohexane) (two sterically demanding $2+$ cations) with the DCL of polyborate anions. The organic ligands 'phen' and 'dac' are drawn schematically in Figure 1. The compounds obtained from these solutions, a tetraborate(2-) salt and two heptaborate(2-) salts have been isolated and characterized by XRD studies and these results are reported herein. Schematic drawings of the structures of the insular tetraborate(2-) and the heptaborate(2-) anions, partnered by appropriate transition-metal complex cations, are also shown in Figure 1.<smiles></smiles>

(a)<smiles>c1cnc2c(c1)ccc1cccnc12</smiles>

(c)

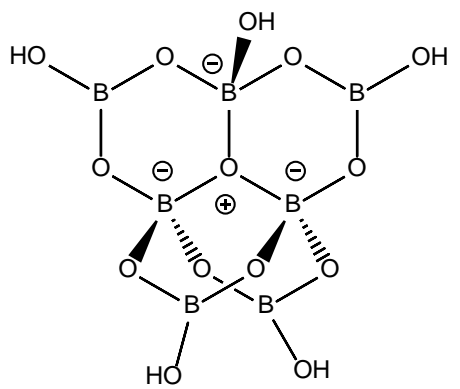

(b)

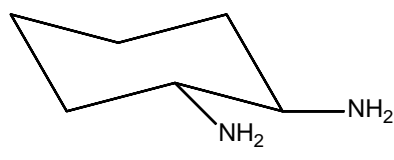

(d)

Figure 1. Schematic drawings of (a) the insular tetraborate(2-) anion, $\left[\mathrm{B}_{4} \mathrm{O}_{5}(\mathrm{OH})_{4}\right]^{2-}$, present in $\left[\mathrm{Co}\left(\mathrm{NH}_{3}\right)_{6}\right]_{2}\left[\mathrm{~B}_{4} \mathrm{O}_{5}(\mathrm{OH})_{4}\right]_{3} \cdot 11 \mathrm{H}_{2} \mathrm{O}(\mathbf{1})$, (b) the insular heptaborate(2-) anion, $\left[\mathrm{B}_{7} \mathrm{O}_{9}(\mathrm{OH})_{5}\right]^{2-}$, present in $\left[\mathrm{Ni}(\text { phen })_{3}\right]\left[\mathrm{B}_{7} \mathrm{O}_{9}(\mathrm{OH})_{5}\right] \cdot 9.5 \mathrm{H}_{2} \mathrm{O}$ (2) and $\left[\mathrm{Zn}(\mathrm{dac})_{2}\left(\mathrm{H}_{2} \mathrm{O}\right)_{2}\right]\left[\mathrm{B}_{7} \mathrm{O}_{9}(\mathrm{OH})_{5}\right] \cdot \mathrm{H}_{2} \mathrm{O}$ (3), (c) phen, $\mathrm{C}_{12} \mathrm{H}_{7} \mathrm{~N}_{2}$, a ligand in 2, and (d) dac, $\mathrm{C}_{6} \mathrm{H}_{12} \mathrm{~N}_{2}$ a ligand in 3. 


\section{EXPERIMENTAL}

\subsection{General}

Chemicals were obtained from commercial sources. $\left[\mathrm{Co}\left(\mathrm{NH}_{3}\right)_{6}\right] \mathrm{Cl}_{3}$ was prepared by a literature method [23]. Fourier transform Infrared spectra (FTIR) were obtained as $\mathrm{KBr}$ pellets over the range 450-4000 $\mathrm{cm}^{-1}$ on a Perkin-Elmer 100 FTIR spectrometer. NMR $\left({ }^{1} \mathrm{H},{ }^{13} \mathrm{C},{ }^{11} \mathrm{~B}\right)$ were obtained on samples dissolved in $\mathrm{D}_{2} \mathrm{O}$ on a Bruker Avance 400 spectrometer. NMR data are reported in ppm with positive chemical shifts $(\delta)$ to high frequency (downfield) of TMS $\left({ }^{1} \mathrm{H},{ }^{13} \mathrm{C}\right)$ and $\mathrm{BF}_{3} \mathrm{OEt}_{2}\left({ }^{11} \mathrm{~B}\right)$. TGA and DSC analysis was performed between $10-800{ }^{\circ} \mathrm{C}$ (in air) on an SDT Q600 V4.1 Build 59 instrument using $\mathrm{Al}_{2} \mathrm{O}_{3}$ crucibles, with a ramp temperature rate of $10{ }^{\circ} \mathrm{C} \mathrm{min}^{-1}$. Magnetic susceptibility measurements were obtained on a Johnson-Matthey balance at room temperature $\left(10{ }^{\circ} \mathrm{C}\right)$. Single-crystal X-ray crystallographic analyses were undertaken at the EPSRC National Crystallography service (University of Southampton). CHN analyses data were obtained from OEA laboratories Ltd in Callington, Cornwall, UK.

\subsection{Synthesis spectroscopic, analytical and crystallographic data for $\left[\mathrm{Co}\left(\mathrm{NH}_{3}\right)_{6}\right]_{2}\left[\mathrm{~B}_{4} \mathrm{O}_{5}(\mathrm{OH})_{4}\right]_{3} \cdot 11 \mathrm{H}_{2} \mathrm{O}(1)$}

An aqueous solution $(10 \mathrm{~mL})$ of $\left[\mathrm{Co}\left(\mathrm{NH}_{3}\right)_{6}\right] \mathrm{Cl}_{3}(0.71 \mathrm{~g}, 2.66 \mathrm{mmol})$ was added to an aqueous suspension (40 mL) of excess $\mathrm{OH}^{-}$-activated Dowex 550A (50 g) monosphere anion exchange resin. The resulting mixture was stirred at room temperature for $24 \mathrm{~h}$. The Dowex 550A resin was separated by filtration with a Buchner funnel and washed with $\mathrm{H}_{2} \mathrm{O}(4 \times 5 \mathrm{~mL})$. The filtrate and washings, containing $\left[\mathrm{Co}\left(\mathrm{NH}_{3}\right)_{6}\right](\mathrm{OH})_{3}$, were reduced to a volume of $15 \mathrm{~mL}$ using a rotary evaporator. $\mathrm{B}(\mathrm{OH})_{3}(1.64 \mathrm{~g}, 26.6$ mmol) was added to the solution and gently warmed with stirring for $2 \mathrm{~h}$. The aqueous solvent was evaporated to $10 \mathrm{~mL}$ using a rotary evaporator and the product, $\left[\mathrm{Co}\left(\mathrm{NH}_{3}\right)_{6}\right]_{2}\left[\mathrm{~B}_{4} \mathrm{O}_{5}(\mathrm{OH})_{4}\right]_{3} \cdot 11 \mathrm{H}_{2} \mathrm{O}$, crystallized from the solution as orange crystals. The product was separated by filtration and dried at 40 ${ }^{\circ} \mathrm{C}$ for 3 h. (0.60 g, 41\%). M.p. $=258-260{ }^{\circ} \mathrm{C}$ (dec.). $\chi_{\mathrm{m}}=-330 \times 10^{-6} \mathrm{~cm}^{3} \mathrm{~mol}^{-1} \cdot \mathrm{B}_{12} \mathrm{Co}_{2} \mathrm{H}_{70} \mathrm{~N}_{12} \mathrm{O}_{38}$. Anal. Calc.: $\mathrm{H}=6.5 \%, \mathrm{~N}=15.4 \%$. Found: $\mathrm{H}=6.5 \%, \mathrm{~N}=15.4 \%$. ${ }^{11} \mathrm{~B} / \mathrm{ppm}: 10.2$. IR $\left(\mathrm{KBr} / \mathrm{cm}^{-1}\right): 3480(\mathrm{~s})$, 3272(s), 1630(m), 1435(s), 1365(s), 1337(s),1160(m), 1063(s), 999(s), 946(m), 818(s). TGA: 70-150 ${ }^{\circ} \mathrm{C}$, loss of 11 interstitial $\mathrm{H}_{2} \mathrm{O}: 17.8 \%$ (18.1\% calc.); $150-350{ }^{\circ} \mathrm{C}$, loss of $12 \mathrm{NH}_{3}$ and $6 \mathrm{H}_{2} \mathrm{O} 28.7 \%(28.5 \%$ calc.); residual $\mathrm{Co}_{2} \mathrm{~B}_{12} \mathrm{O}_{21} 53.5 \%$ (53.3\% calc.). Crystal data: $\mathrm{B}_{12} \mathrm{Co}_{2} \mathrm{H}_{70} \mathrm{~N}_{12} \mathrm{O}_{38}, M_{r}=1094.26$, monoclinic, $P 22_{1} / c, a=21.8485(3) \AA, \quad b=8.85340(10) \AA, c=21.6352(3) \AA, \alpha=\gamma=90^{\circ}, \quad \beta=$ 101.3410(10) $, V=4103.26(9) \AA^{3}, T=100(2) \mathrm{K}, Z=4, \mu\left(\mathrm{MoK}_{\alpha}\right)=0.937 \mathrm{~mm}^{-1}$, 50,435 reflections measured, 9416 unique $\left(R_{\text {int }}=0.0245\right)$ which were used in all calculations. The final $w R_{2}$ was 0.0629 (all data) and $R_{1}$ was 0.0252 (I $>2 \sigma(\mathrm{I})$ ). 


\subsection{Synthesis spectroscopic, analytical and crystallographic data for $\left[\mathrm{Ni}(\text { phen })_{3}\right]\left[\mathrm{B}_{7} \mathrm{O}_{9}(\mathrm{OH})_{5}\right] \cdot 9.5 \mathrm{H}_{2} \mathrm{O}(2)$}

An aqueous solution ( $5 \mathrm{~mL}$ ) of 1,10-phen ( $5.4 \mathrm{~g}, 30 \mathrm{mmol})$ was added to an aqueous solution $(10 \mathrm{~mL})$ of $\mathrm{NiSO}_{4} \cdot 6 \mathrm{H}_{2} \mathrm{O}$ (2.6 g, $10 \mathrm{mmol}$ ). The reaction mixture was stirred at room temperature for $1.5 \mathrm{~h}$, and then an aqueous solution $(15 \mathrm{~mL})$ of $\mathrm{Ba}(\mathrm{OH})_{2} \cdot 8 \mathrm{H}_{2} \mathrm{O}(3.1 \mathrm{~g}, 10 \mathrm{mmol})$ was added. The reaction mixture was stirred for a further $0.5 \mathrm{~h}$ and then filtered by gravity. An aqueous solution $(15 \mathrm{~mL}) \mathrm{of} \mathrm{B}(\mathrm{OH})_{3}(6.2$ g, $100 \mathrm{mmol}$ ) was added to the filtrate and the solution was stirred at room temperature for a further 2 h. The volume of the solution was reduced to $20 \mathrm{~mL}$ (rotary evaporator) and the solution was distributed over a few small vials and left $(10 \mathrm{~d})$ to afford pink crystals of $\left[\mathrm{Ni}(\text { phen })_{3}\right]\left[\mathrm{B}_{7} \mathrm{O}_{9}(\mathrm{OH})_{5}\right] \cdot 9.5 \mathrm{H}_{2} \mathrm{O}(4.3 \mathrm{~g}$. $40 \%)$ which were isolated by filtration. M.p. $>300{ }^{\circ} \mathrm{C}$ (dec.). $\chi_{\mathrm{m}}=3220 \times 10^{-6} \mathrm{~cm}^{3} \mathrm{~mol}^{-1}$. $\mathrm{C}_{36} \mathrm{H}_{48} \mathrm{~B}_{7} \mathrm{~N}_{6} \mathrm{NiO}_{23.5}$. Anal. Calc.: $\mathrm{C}=40.2 \%, \mathrm{H}=4.5 \%, \mathrm{~N}=7.8 \%$. Found: $\mathrm{C}=39.8 \%, \mathrm{H}=4.8 \%, \mathrm{~N}=$ 7.6\%. ${ }^{11} \mathrm{~B} / \mathrm{ppm}$ : 14.87. IR (KBr/cm-1): 3393(s), 1648(m), 1519(m), 1426(s), 1338(s), 1164(s), 1147(s), 1071(s), 848(s), 803(s), 726(s). TGA: $100-220^{\circ} \mathrm{C}$, loss of interstitial $9.5 \mathrm{H}_{2} \mathrm{O}: 16.6 \%$ (16.0\% calc.); 220$340{ }^{\circ} \mathrm{C}$, condensation of polyborate which loss of $2.5 \mathrm{H}_{2} \mathrm{O}: 5.4 \%$ (4.2\% calc.); 340-750 ${ }^{\circ} \mathrm{C}$, oxidation of organic content $49.0 \%$ (50.0\% calc.); residual $\mathrm{NiB}_{7} \mathrm{O}_{11.5} 29.0 \%$ (29.7\% calc.). Crystal data: $\mathrm{C}_{36} \mathrm{H}_{48} \mathrm{~B}_{7} \mathrm{~N}_{6} \mathrm{NiO}_{23.5}, M_{r}=1075.18$, monoclinic, $I a$ (No. 9), a = 26.4855(3) $\AA, \mathrm{b}=15.86160(10) \AA, \mathrm{c}=$ 25.0865(3) $\AA, \beta=115.2530(10)^{\circ}, \alpha=\gamma=90^{\circ}, V=9531.72(18) \AA^{3}, T=100(2) \mathrm{K}, Z=8, Z^{\prime}=2$, $\mu\left(\mathrm{CuK}_{\alpha}\right)=1.385 \mathrm{~mm}^{-1}, 47968$ reflections measured, 16407 unique $\left(R_{\text {int }}=0.0416\right)$ which were used in all calculations. The final $w R_{2}$ was 0.1758 (all data) and $R_{1}$ was 0.0609 (I $>2 \sigma(\mathrm{I})$ ).

\subsection{Synthesis spectroscopic, analytical and crystallographic data for $\left[\mathrm{Zn}(\mathrm{dac})_{2}\left(\mathrm{H}_{2} \mathrm{O}\right)_{2}\right]\left[\mathrm{B}_{7} \mathrm{O}_{9}(\mathrm{OH})_{5}\right] \cdot \mathrm{H}_{2} \mathrm{O}(3)$}

An aqueous solution (20 mL) of cis-/trans-1,2-( $\left(\mathrm{NH}_{2}\right)_{2} \mathrm{C}_{6} \mathrm{H}_{10}(2.3 \mathrm{~g}, 20 \mathrm{mmol})$ was added to an aqueous solution (5 mL) of $\mathrm{ZnSO}_{4} \cdot \mathrm{H}_{2} \mathrm{O}(1.8 \mathrm{~g}, 10 \mathrm{mmol})$. The reaction mixture was stirred for $0.1 \mathrm{~h}$, and then an aqueous solution $(15 \mathrm{~mL})$ of $\mathrm{Ba}(\mathrm{OH})_{2} \cdot 8 \mathrm{H}_{2} \mathrm{O}(3.1 \mathrm{~g}, 10 \mathrm{mmol})$ was added. The reaction mixture was stirred for a further $0.5 \mathrm{~h}$ and then filtered to remove $\mathrm{BaSO}_{4}$. An aqueous solution $(20 \mathrm{~mL})$ of $\mathrm{B}(\mathrm{OH})_{3}$ (6.2 g, $100 \mathrm{mmol}$ ) was added to the filtrate and the solution was stirred at room temperature for $2 \mathrm{~h}$. The solution was then distributed over several vials and left for 14 days to yield to crystallize as colourless/light pink crystals of $\left[\mathrm{Zn}(\mathrm{dac})_{2}\left(\mathrm{H}_{2} \mathrm{O}\right)_{2}\right]\left[\mathrm{B}_{7} \mathrm{O}_{9}(\mathrm{OH})_{5}\right] \cdot \mathrm{H}_{2} \mathrm{O}\left(3.2\right.$ g, 49\%). M.p. $=260-265{ }^{\circ} \mathrm{C}$ (dec.). $\chi_{\mathrm{m}}=-290 \times 10^{-6} \mathrm{~cm}^{3} \mathrm{~mol}^{-1} \cdot \mathrm{C}_{12} \mathrm{H}_{39} \mathrm{~B}_{7} \mathrm{~N}_{4} \mathrm{O}_{17} \mathrm{Zn}$. Anal. Calc.: $\mathrm{C}=22.1 \%, \mathrm{H}=6.0 \%, \mathrm{~N}=8.6 \%$. found: $\mathrm{C}=22.0 \%, \mathrm{H}=6.1 \%, \mathrm{~N}=8.7 \% .{ }^{11} \mathrm{~B} / \mathrm{ppm}$ : 16.83. IR $\left(\mathrm{KBr} / \mathrm{cm}^{-1}\right)$ : 3341(s), 3284(s), 2933(m), 2861(w), 1610(m), 1417(s), 1373(s), 1259(s), 1203(s), 1137(s), 1088(s), 1016(s), 956(m), 898(m), 850(s), 807(s). TGA: $100-200{ }^{\circ} \mathrm{C}, 1$ interstitial and 2 coordinated $\mathrm{H}_{2} \mathrm{O} 8.1 \%$ (8.3\% calc.); $200-400{ }^{\circ} \mathrm{C}$, condensation of polyborate with loss of further $2.5 \mathrm{H}_{2} \mathrm{O}: 7.9 \%$ (6.9\% calc.); $400-700{ }^{\circ} \mathrm{C}$, oxidation of organic content $34.3 \%$ (34.9\% calc.); residual $\mathrm{ZnB}_{7} \mathrm{O}_{11.5} 49.7 \%$ (49.8\% calc.). Crystal data: 
$\mathrm{C}_{12} \mathrm{H}_{39} \mathrm{~B}_{7} \mathrm{~N}_{4} \mathrm{O}_{17} \mathrm{Zn}, M_{r}=652.51$, monoclinic, C2/c (No. 15), a = 22.4387(3) $\AA, \mathrm{b}=10.96310(10) \AA, \mathrm{c}=$ 23.0303(3) $\AA, \beta=108.3600(10)^{\circ}, \alpha=\gamma=90^{\circ}, V=5377.01(12) \AA^{3}, T=100(2) \mathrm{K}, Z=8, Z^{\prime}=1$, $\mu\left(\mathrm{MoK}_{\alpha}\right)=0.997 \mathrm{~mm}^{-1}, 33978$ reflections measured, 6166 unique $\left(R_{\text {int }}=0.0226\right)$ which were used in all calculations. The final $w R_{2}$ was 0.0987 (all data) and $R_{1}$ was $0.0351(\mathrm{I}>2 \sigma(\mathrm{I})$ ).

\subsection{X-ray crystallography for 1,2 and 3.}

Suitable crystals of 1, $\mathbf{2}$ and $\mathbf{3}$ was selected and mounted on MITIGEN holders in perfluoroether oil. A Rigaku AFC12 goniometer equipped with an enhanced sensitivity (HG) Saturn724+ detector mounted at the window of an FR-E+ SuperBright molybdenum rotating anode generator with VHF Varimax


007HF equipped with Varimax confocal mirrors and an AFC11 goniometer and HyPix 6000 detector diffractometer was used for 2. Crystals were kept at $T=100(2) \mathrm{K}$ during data collection. Cell determination and data collection for 1 were performed using CrystalClear-SM Expert 3.1 b27 [24] whilst cell determination and data collection for $\mathbf{2}$ and $\mathbf{3}$ were performed using CrysAlisPro [25] that was also used for all data reduction, scaling and corrections. Using Olex2 [26] the structures were solved with the ShelXT [27] structure solution program by the Intrinsic Phasing solution method. The models were refined with SHELXL-2018/3 [28] using Least Squares minimisation.

\section{RESULTS AND DISCUSSION}

\subsection{Synthesis}

The new compounds $\left[\mathrm{Co}\left(\mathrm{NH}_{3}\right)_{6}\right]_{2}\left[\mathrm{~B}_{4} \mathrm{O}_{5}(\mathrm{OH})_{4}\right]_{3} \cdot 11 \mathrm{H}_{2} \mathrm{O}(\mathbf{1})$, $\left[\mathrm{Ni}(\mathrm{phen})_{3}\right]\left[\mathrm{B}_{7} \mathrm{O}_{9}(\mathrm{OH})_{5}\right] \cdot 9.5 \mathrm{H}_{2} \mathrm{O}$ (2), and $\left[\mathrm{Zn}(\mathrm{dac})_{2}\left(\mathrm{H}_{2} \mathrm{O}\right)_{2}\right]\left[\mathrm{B}_{7} \mathrm{O}_{9}(\mathrm{OH})_{5}\right] \mathrm{H}_{2} \mathrm{O}$ (3) were obtained from the reaction of the appropriate transitionmetal complex (with [OH] $]^{-}$counterions) and ten equivalents of $\mathrm{B}(\mathrm{OH})_{3}$ as shown in Equations 1-3. The transition-metal complexes with $[\mathrm{OH}]^{-}$counterions were prepared in situ from the corresponding $\mathrm{Cl}^{-}$salt (for $\mathbf{1}$ ) or $\mathrm{SO}_{4}{ }^{2-}$ salts (for $\mathbf{2}$ and $\mathbf{3}$ ) using either ion exchange resin (for $\mathbf{1}$ ) or metathesis reactions with $\mathrm{Ba}(\mathrm{OH})_{2}$ (for 2 and $\mathbf{3}$ ).

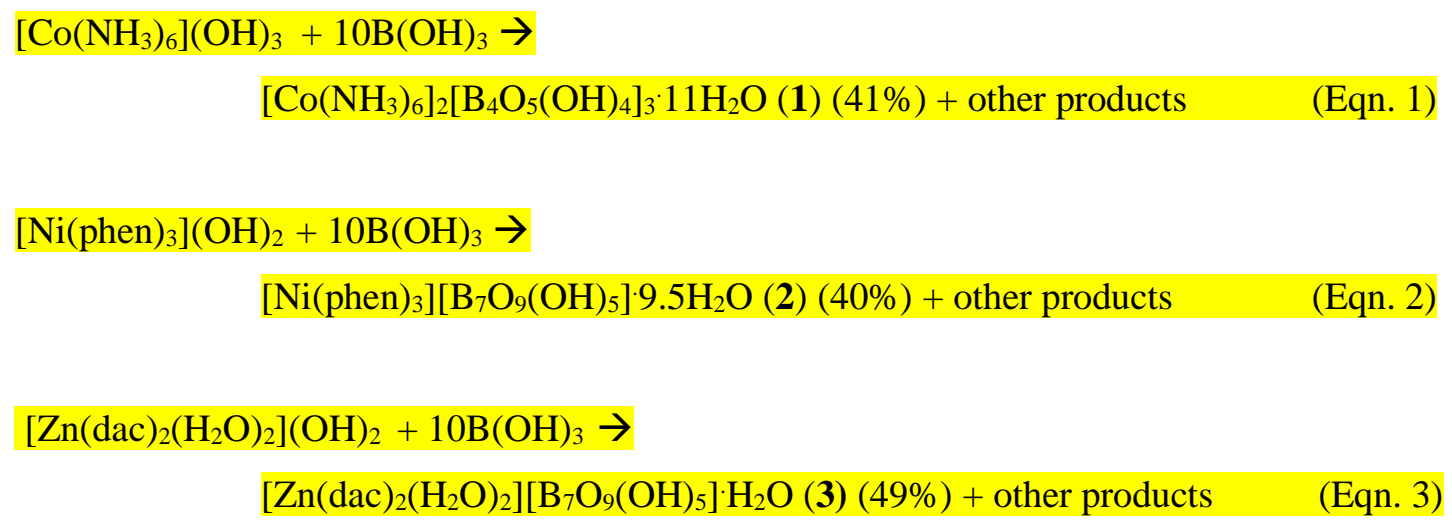


Compounds 1-3 were prepared in moderate yields (40-49\%) and characterized by magnetic susceptibilty measurements, spectroscopic (IR, NMR) and thermal (TGA/DSC) analysis (Section 3.2) and by singlecrystal XRD studies (Section 3.3). Compounds 1-3 are formulated as ionic solids containing transitionmetal complex cations, insular polyborate anions, and waters of crystallization. Elemental analysis of bulk samples were consistent with their formulations obtained by crystallography and thermal studies and single-crystal diffraction studies, indicating that the crystals chosen for XRD analyses were representative of bulk samples.

Compounds 1-3 crystallized from aqueous solution as ionic salts through cation templated self-assembly processes from the DCL of polyborate anions present in the basic solutions. Pentaborate(1-) salts are easily synthesised by this methodology particularly when the cations are organic and are not too sterically demanding [16-19]. Such non-metal cation salts usually exist as giant 3-dimensional pentaborate(1-) networks with cations situated within the cavities [7,17,29]; the networks are held together through strong $\mathrm{R}_{2}{ }^{2}(8)$ [19,30] anion-anion $\mathrm{H}$-bonds between neighbouring pentaborate(1-) moieties. The driving force partly responsible for the formation of these pentaborate(1-) salts is the formation of the energetically favourable anion-anion H-bonded networks. The strategy of using sterically demanding, more highly charged $(>+1)$, transition-metal complex cations to template nonpentaborate(1-) salts has been successful since a tetraborate(2-) and two heptaborate(2-) salts have been formed. The templating cations are too large to be accommodated within a simple pentaborate(1-) lattice $[19,22]$ and therefore template other structures. The cations in $\mathbf{1}$ and $\mathbf{3}$ are not only large but also has the potential to form many energetically favourable H-bond cation-anion donor interactions. These additional interactions facilitate the formation of non-pentaborate(1-) salts. The solid-state structures of 1-3, including their H-bond interactions are discussed in detail in Section 3.3.

\subsection{Magnetic, spectroscopic and thermal studies}

Magnetic susceptibility measurements on 1-3 were determined at room temperature by using a Evans (Johnson-Matthey) balance [31]. These measurements confirmed the expected magnetic properties of the salts with compounds $\mathbf{1}\left(\mathrm{d}^{6}, \mathrm{Co}^{3+}\right)$ and $\mathbf{3}\left(\mathrm{d}^{10}, \mathrm{Zn}^{2+}\right)$ diamagnetic and compound $\mathbf{2}\left(\mathrm{d}^{8}, \mathrm{Ni}^{2+}\right)$ paramagnetic. The observed $\mu_{\text {eff }}$ of 2.77 BM for 2 corresponds well with the calculated spin-only $\mu_{\mathrm{s} .0}$. value for 2 unpaired electrons, (2.82 BM) and is consistent with $\mu_{\text {eff }}$ values for other octahedral $\mathrm{Ni}^{2+}$ complexes [32]. Attempts were made to obtain NMR data on 1-3 but these compounds were all insoluble in organic solvents and only dissolved (with decomposition) in $\mathrm{D}_{2} \mathrm{O}$. The decomposition occurs in aqueous solution as the DCL's of the original starting species are reformed. ${ }^{11} \mathrm{~B}$ NMR spectra of these decomposition solutions were obtained for 1-3 and these all show just 1 peak consistent with fast $\mathrm{B}(\mathrm{OH})_{3} /\left[\mathrm{B}(\mathrm{OH})_{4}\right]^{-}$exchange [14]. The ${ }^{11} \mathrm{~B}$ signal originating from the decomposition 1 was upfield 
of those observed for those originating from the decomposition of in $\mathbf{2}$ and $\mathbf{3}$. The observed ${ }^{11} \mathrm{~B}$ chemical shifts for $\mathbf{1}$ and $\mathbf{2}$ were in agreement with shifts calculated from the boron/charge ratio [14,19] whereas $\mathbf{3}$ was slightly more downfield than expected. The ${ }^{1} \mathrm{H}$ spectra of $\mathbf{1}$ was not reported since it only contains exchangeable $\mathrm{H}$ atoms on $\mathrm{NH}_{3}$ ligands and ${ }^{1} \mathrm{H}$ and ${ }^{13} \mathrm{C}$ spectra of 2 were not obtained due to the paramagnetic nature of the metal complex. ${ }^{1} \mathrm{H}$ and ${ }^{13} \mathrm{C}$ spectra of $\mathbf{3}$ were obtained (see Supplementary Information) but are not reported since they were not characteristic of the salt and indicated that the $\mathrm{Zn(II)} \mathrm{complex} \mathrm{was} \mathrm{also} \mathrm{labile} \mathrm{and} \mathrm{that} \mathrm{an} \mathrm{equilibrium} \mathrm{mixture} \mathrm{was} \mathrm{present.}$

IR spectra of polyborate species may be assigned with reference to Li et al. [33], The strong bands in the B-O region of the tetraborate(2-) salt, $\mathbf{1}$, are therefore assigned as $v_{a s}\left(B_{(3)}-O\right)(1435,1365$ and $\left.1337 \mathrm{~cm}^{-1}\right), v_{\text {as }}\left(\mathrm{B}_{(4)}-\mathrm{O}\right)\left(1063,999 \mathrm{~cm}^{-1}\right), v_{\mathrm{s}}\left(\mathrm{B}_{(3)}-\mathrm{O}\right)\left(946 \mathrm{~cm}^{-1}\right)$ and $v_{\mathrm{s}}\left(\mathrm{B}_{(4)}-\mathrm{O}\right)\left(818 \mathrm{~cm}^{-1}\right)$. IR spectra of the heptaborate(2-) ion contained in $\mathbf{2}$ and $\mathbf{3}$ are not specifically included in work of Li et al. [33] but similar general assignments are possible. Bands at 905 and $860 \mathrm{~cm}^{-1}$ have been observed in both the non-metal cation salts $\quad\left[\text { cyclo- } \mathrm{C}_{6} \mathrm{H}_{11} \mathrm{NH}_{3}\right]_{2}\left[\mathrm{~B}_{7} \mathrm{O}_{9}(\mathrm{OH})_{5}\right] .3 \mathrm{H}_{2} \mathrm{O} \cdot \mathrm{B}(\mathrm{OH})_{3}$ and [cyclo$\left.\mathrm{C}_{7} \mathrm{H}_{13} \mathrm{NH}_{3}\right]_{2}\left[\mathrm{~B}_{7} \mathrm{O}_{9}(\mathrm{OH})_{5}\right] .2 \mathrm{H}_{2} \mathrm{O} \cdot 2 \mathrm{~B}(\mathrm{OH})_{3}$ and were previously proposed as diagnostic for this anion [34]. Since then further synthetic and IR studies on $\left[\mathrm{C}_{10} \mathrm{H}_{22} \mathrm{~N}_{2}\right]\left[\mathrm{B}_{7} \mathrm{O}_{6}(\mathrm{OH})_{5}\right] \cdot 2 \mathrm{H}_{2} \mathrm{O}$ [22] and $\left[\mathrm{Cu}(\mathrm{dac})_{2}\left(\mathrm{H}_{2} \mathrm{O}\right)_{2}\right]\left[\mathrm{Cu}(\mathrm{dac})_{2}\right]\left[\mathrm{B}_{7} \mathrm{O}_{9}(\mathrm{OH})_{5}\right]_{2} \cdot 4 \mathrm{H}_{2} \mathrm{O}$ [35] have only confirmed the lower energy band, indicating that the $905 \mathrm{~cm}^{-1}$ band in the original study probably had $\mathrm{B}(\mathrm{OH})_{3} /$ organic-based origins. In agreement with this, compounds 2 and 3 show strong bands in the $v_{s}\left(B_{(4)}-O\right)$ region at 848 and $850 \mathrm{~cm}^{-}$ ${ }^{1}$, respectively.

TGA plots were obtained for compounds 1-3 (in air) over the temperature range $20-800{ }^{\circ} \mathrm{C}$ (see Supplementary Information). Compounds 1-3 thermally decompose in air to afford anhydrous metal borates of composition $\mathrm{CoB}_{6} \mathrm{O}_{10.5}, \mathrm{NiB}_{7} \mathrm{O}_{11.5}$ and $\mathrm{ZnB}_{7} \mathrm{O}_{11.5}$, respectively. These specific metal/boron ratios are in accord with their original stoichiometries in 1-3. Such behaviour has been noted before for polyborate salts containing transition-metal complexes [20,21,35-40]. Interestingly, the decomposition process is concluded by $\sim 400{ }^{\circ} \mathrm{C}$ for 1 but temperatures in excess of $700{ }^{\circ} \mathrm{C}$ are required for both 2 and 3. This may be explained since for $\mathbf{1}$ steps involving the loss of interstitial $\mathrm{H}_{2} \mathrm{O}$, loss of coordinated $\mathrm{NH}_{3}$ and loss of $\mathrm{H}_{2} \mathrm{O}$ through polyborate condensation are observed. Compounds $\mathbf{2}$ and $\mathbf{3}$ also lose interstitial $\mathrm{H}_{2} \mathrm{O}$ and undergo loss of $\mathrm{H}_{2} \mathrm{O}$ through polyborate condensation at lower temperatures, but differ from 1 in that they also possess organic ligands and these are lost through oxidative processes which occur at higher temperatures.

\subsection{Crystallographic studies}

Compound 1 is formulated as $\left[\mathrm{Co}\left(\mathrm{NH}_{3}\right)_{6}\right]_{2}\left[\mathrm{~B}_{4} \mathrm{O}_{5}(\mathrm{OH})_{4}\right]_{3} \cdot 11 \mathrm{H}_{2} \mathrm{O}$ and crystallographically contains three $\left[\mathrm{Co}\left(\mathrm{NH}_{3}\right)_{6}\right]^{3+}$ cations, with two of them bisected by an internal plane of symmetry and therefore equating 
to one, three independent $\left[\mathrm{B}_{4} \mathrm{O}_{5}(\mathrm{OH})_{4}\right]^{2-}$ anions and eleven interstitial waters of crystallization. A thermal ellipsoid drawing of these components is shown in Figure 2.

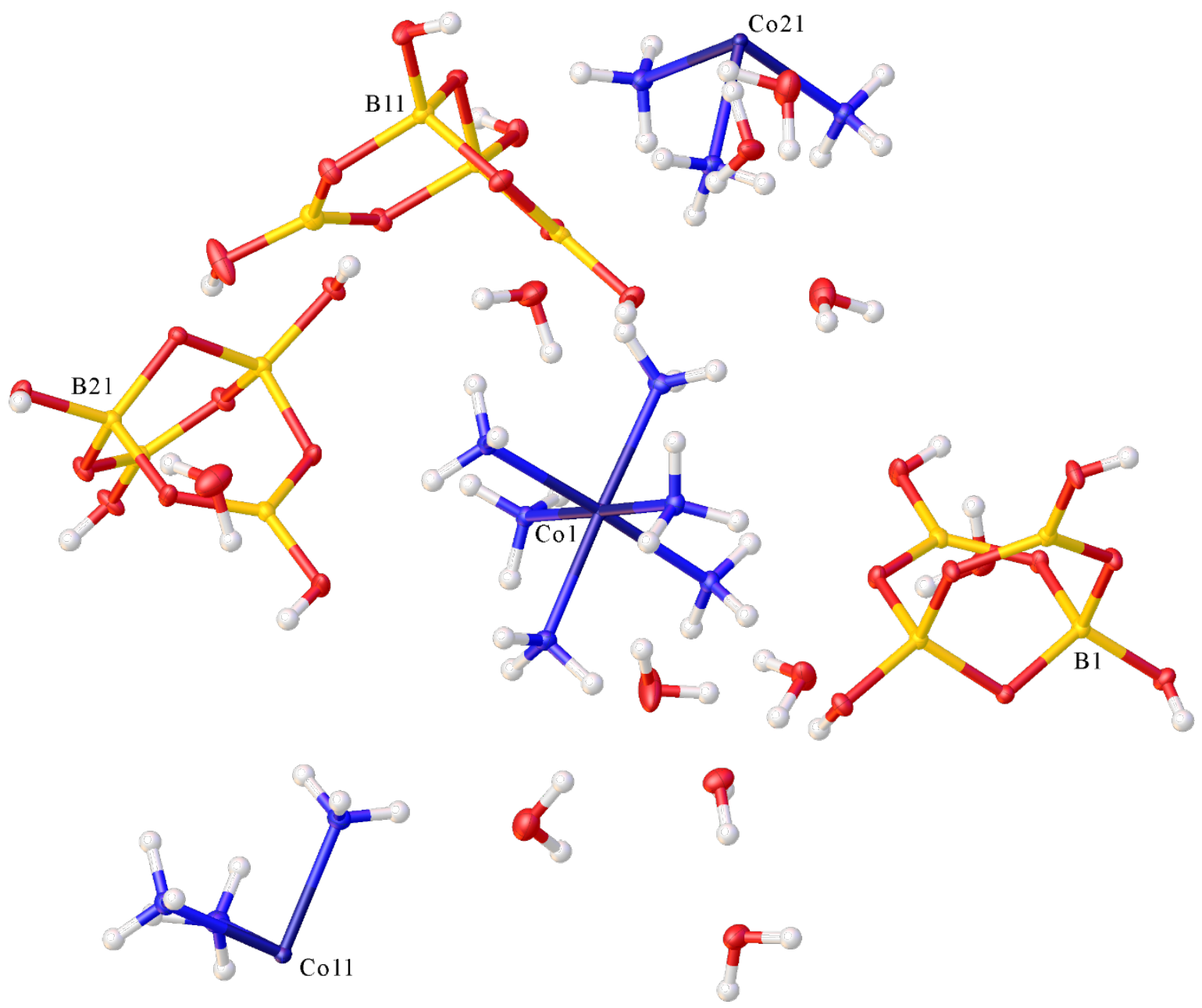

Figure 2. Crystal diagram showing the asymmetric unit of $\mathbf{1}$ with basic atomic numbering scheme.

The $\left[\mathrm{Co}\left(\mathrm{NH}_{3}\right)_{6}\right]^{3+}$ cations are octahedral with Co-N bond lengths ranging from 1.9557(12)-1.9761(12) $\AA$ and are typical of those observed in other reported $\left[\mathrm{Co}\left(\mathrm{NH}_{3}\right)_{6}\right]^{3+}$ salts [41]. The tetraborate(2-) anion is well-known with the structural descriptor [42] of 4-1:2A +2T. It occurs in borax, $\mathrm{Na}_{2}\left[\mathrm{~B}_{4} \mathrm{O}_{5}(\mathrm{OH})_{4}\right] \cdot 8 \mathrm{H}_{2} \mathrm{O}[43]$ and a number of other crystallographically determined structures with bond lengths and bond-angles in agreement with data published for transition-metal complex tetraborates [4446] and non-metal cation tetraborates [47-49]. The tetraborate(2-) anions H-bond together to a giant supramolecular anionic network. These $\mathrm{H}$-bond interactions are of two types: numerous pairwise $\mathrm{R}_{2}{ }^{2}(8)$ interactions and many simple D interactions incorporated into complex polymeric chains (Etter 
nomenclature [30]). Pairwise $\mathrm{R}_{2}{ }^{2}(8)$ interactions are known to be particularly energetically favourable and dominate the energetics of more commonplace pentaborate(1-) structures [19]. Diagrams of these anion-anion interactions can be seen in the Supplementary Information (Figures S1-S4), and full details of all the H-bond interactions are available in the Supplementary Information. The potential of $\left[\mathrm{Co}\left(\mathrm{NH}_{3}\right)_{6}\right]^{3+}$ cations as a multi-H-bond donors is noted in the introduction. It is evident that cationanion interactions also make significant contribution to stabilizing the supramolecular H-bonded tetraborate(2-) network since the crystallographic cations in compound $\mathbf{1}$ use all amino hydrogen atoms in donor interactions to either tetraborate(2-) anions or interstitial $\mathrm{H}_{2} \mathrm{O}$ molecule. A drawing the secondary coordination sphere around Co1 is shown in Figure 3 where it can be seen to form donor interactions with six tetraborate(2-) anions (and six $\mathrm{H}_{2} \mathrm{O}$ molecules, not shown). The combination of these cation-anion $\mathrm{H}$-bond interactions, together with the strong pairwise $\mathrm{R}_{2}^{2}(8)$ anion-anion $\mathrm{H}$-bond interactions, are implicated in the preference of this system to self-assemble into a tetraborate(2-) salt rather than pentaborate(1-) salt. However, other factors such as charge on the cation (> 1), steric effects, stoichiometry, and packing must also play important roles.



Figure 3. The H-bond interactions of the $\left[\mathrm{Co}\left(\mathrm{NH}_{3}\right)_{6}\right]^{3+}$ cation in 1 containing $\mathrm{Co} 1$ with six tetraborate(2-) anions. Additional interactions with $\mathrm{H}_{2} \mathrm{O}$ molecules exist but are not shown. 
Compound 2 is formulated as $\left[\mathrm{Ni}(\text { phen })_{3}\right]\left[\mathrm{B}_{7} \mathrm{O}_{9}(\mathrm{OH})_{5}\right] \cdot 9.5 \mathrm{H}_{2} \mathrm{O}$ with the crystallographic asymmetric unit of the crystallographic cell comprised of two independent $\left[\mathrm{Ni}(\text { phen })_{3}\right]^{2+}$ cations, two independent $\left[\mathrm{B}_{7} \mathrm{O}_{9}(\mathrm{OH})_{5}\right]^{2-}$ anions and 19 waters of crystallization; there is disorder in some of these $\mathrm{H}_{2} \mathrm{O}$ molecules. A thermal ellipsoid drawing of the structure of $\mathbf{2}$ is shown in Figure 4. The cations in $\mathbf{2}$ are both essentially distorted octahedral with Ni-N bonds lengths not significantly and range from 2.082(5)2.098(5) $\AA$ (Ni1) and 2.086(5)-2.108(6) $\AA$ (Ni2). The narrow bite of the phen ligand imposes three N$\mathrm{Ni}-\mathrm{N}$ angles per cation significantly smaller [av. $\left.79.7(2)^{\circ}\right]$ than the $90^{\circ}$ angles expected for an octahedral arrangement and also influences the magnitude of the trans angles. The cations in $\mathbf{2}$ are chiral with the $\Delta$ configuration adopted for the cation containing Ni1 whereas the cation containing Ni2 has the $\Lambda$ configuration [50]. The average Ni-N bond lengths (2.095(8) $\AA$ ) and N-Ni-N angles [169.3(2) ${ }^{\circ}, 90.1(2)^{\circ}$ ] are in accord with literature values for other reported [Ni(phen) $\left.]_{3}\right]^{2+}$ cations [51].

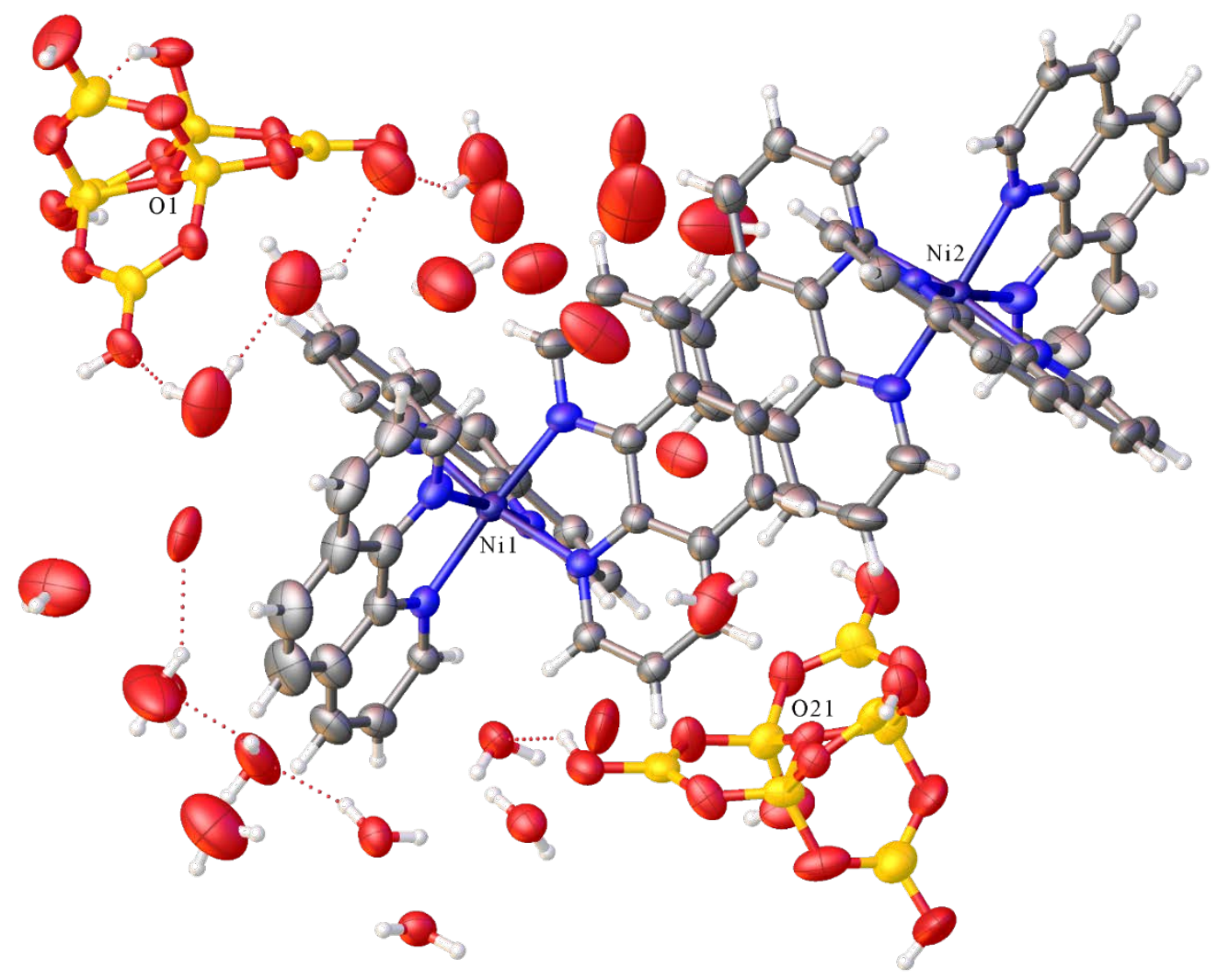

Figure 4. Structure of 2 showing (selected) atomic numbering scheme.

Compound 3 is formulated as $\left[\mathrm{Zn}(\mathrm{dac})_{2}\left(\mathrm{H}_{2} \mathrm{O}\right)_{2}\right]\left[\mathrm{B}_{7} \mathrm{O}_{9}(\mathrm{OH})_{5}\right] \cdot \mathrm{H}_{2} \mathrm{O}$ and has the asymmetric unit of the crystallographic unit cell comprised of a $\left[\mathrm{B}_{7} \mathrm{O}_{9}(\mathrm{OH})_{5}\right]^{2-}$ anion partnered with two independent 'halfcations' of $\left[\mathrm{Zn}(\mathrm{dac})_{2}\left(\mathrm{H}_{2} \mathrm{O}\right)_{2}\right]^{2+}$ and a water of crystallization (Figure 5); the cations are disordered into two components. Each independent cation has a distorted octahedral geometry with two $\mathrm{H}_{2} \mathrm{O}$ ligands 
trans and the two dac ligands arranged centrosymetrically around the zinc(II) centre. The cyclohexyl rings of the dac ligands in $\mathbf{3}$ are in chair conformations with their amino groups equatorial. The stereochemistry of one dac ligand of each cation is is $R, R$ whilst the other dac ligand has $S, S$ stereochemistry. Zn-O and $\mathrm{Zn}-\mathrm{N}$ bond lengths are not significantly different to data from known distorted octahedral aqua or amine zinc(II) complexes [52].

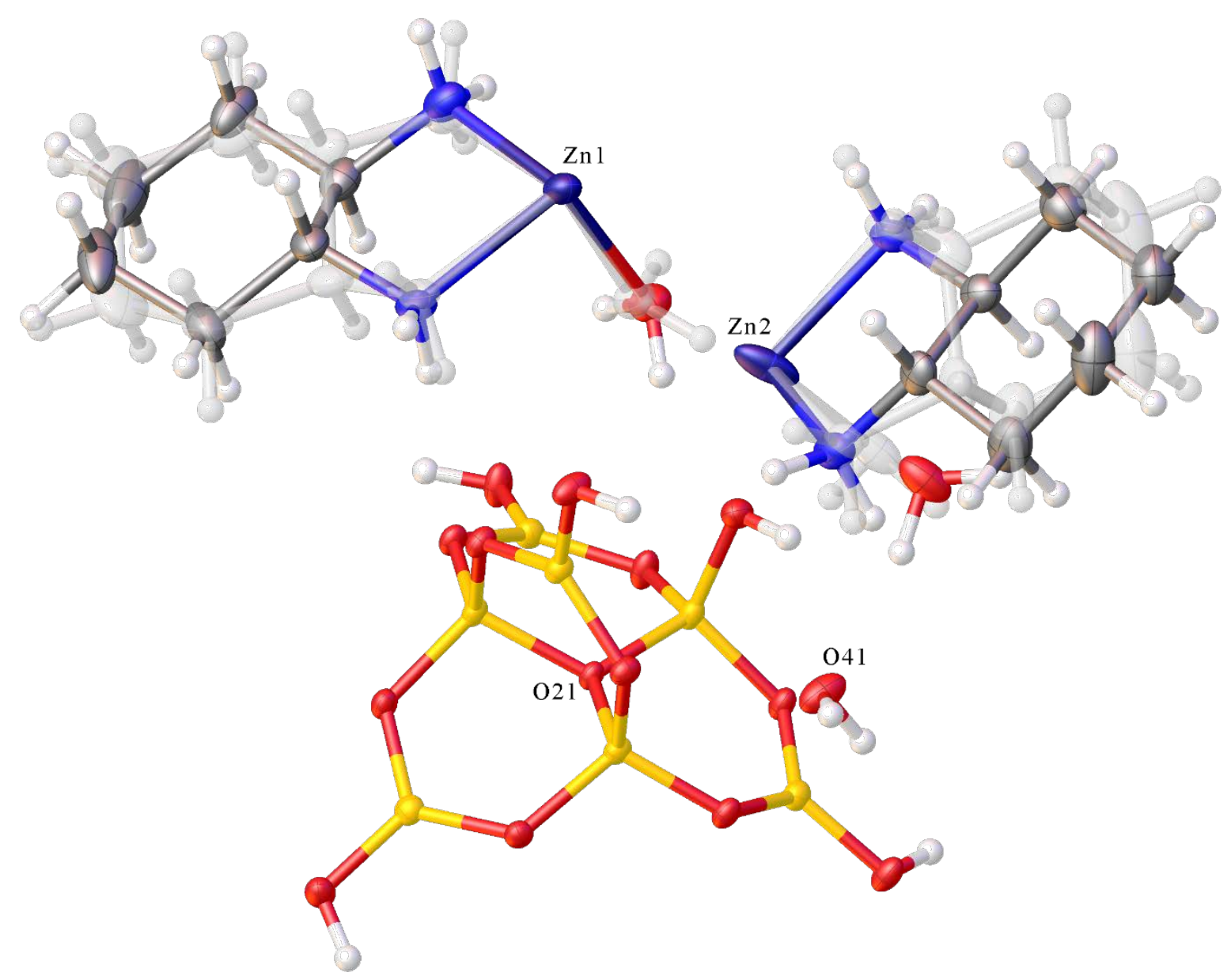

Figure 5. Structure of $\mathbf{3}$ showing $\left[\mathrm{B}_{7} \mathrm{O}_{9}(\mathrm{OH})_{5}\right]^{2-}$ anion partnered with two independent 'half-cations' of $\left[\mathrm{Zn}(\mathrm{dac})_{2}\left(\mathrm{H}_{2} \mathrm{O}\right)_{2}\right]^{2+}$ and a water of crystallization. (The lesser components of disordered dac is shown in light grey.

Compounds 2 and 3 both contain structurally similar insular $\left[\mathrm{B}_{7} \mathrm{O}_{9}(\mathrm{OH})_{5}\right]^{2-}$ anions and these are conveniently discussed together. There are two known insular heptaborate(2-) anions and these have been referred to in the literature as the 'chain' isomer or the ' $\mathrm{O}^{+}$' isomer [7]. Compounds $\mathbf{2}$ and $\mathbf{3}$ are 
both further examples of this ' $\mathrm{O}^{+}$' isomer (Figure $1 \mathrm{~b}$ ) and this isomer has the structural descriptor [42] of $6:(3 \Delta+3 T)+\Delta$. Salts containing this ' $\mathrm{O}^{+}$' isomer are rare and examples are limited to four organiccation salts $[22,34,53]$ and two transition-metal complex cation salts $[35,54]$. The ' $\mathrm{O}^{+}$' isomer of the heptaborate(2-), has the characteristic structural motif of a pyramidal 3-coordinate $\mathrm{O}$ atom (bearing a formal positive charge) bound to three 4-coordinate B centres (each bearing formal negative charges). In 2 these oxygen atoms are $\mathrm{O} 1$ and $\mathrm{O} 21$ for the two independent anions and in $\mathbf{3}$ it is $\mathrm{O} 21$. The $\mathrm{O} 1$ and $\mathrm{O} 21$ to B bond lengths (in 2) vary from 1.499(8)-1.532(6) $\AA$ and those for O21 (in 3) range from 1.5086(19)-1.5152(19) A. These distances are significantly longer than the other B-O distances in the anion which are in the usual ranges for $\mathrm{B}_{\text {trig- }} \mathrm{O}$ and $\mathrm{B}_{\text {tet }}-\mathrm{O}$ bonds $[16-22,34,35,53,54]$. As expected, these $\mathrm{O}^{+}$atoms are pyramidal with O-B-O angles sums of 347.9(4) ${ }^{\circ}$ and $349.0(5)^{\circ}$ (in 2) and 349.59(11) ${ }^{\circ}$ (in 3). Other $\mathrm{B}-\mathrm{O}-\mathrm{B}, \mathrm{O}-\mathrm{B}_{\text {trig }}-\mathrm{O}$ and $\mathrm{O}-\mathrm{B}_{\text {tet }}-\mathrm{O}$ angles are within the usual ranges observed in polyborate and related boroxole species [16-22,34,35,53-57].

Since cation-anion $\mathrm{H}$ bond donor interactions can strongly influence the observed templated polyborate structures (e.g. as in 1) it is important to examine the potential cation H-bond donor sites in $\mathbf{2}$ and $\mathbf{3}$. There are no potential H-bond cation donor sites in $\mathbf{2}$. The supramolecular architecture of $\mathbf{2}$ is discussed in detail in the next paragraph. Compound $\mathbf{3}$ is structurally very similar to $\left[\mathrm{Cu}(\mathrm{dac})_{2}\left(\mathrm{H}_{2} \mathrm{O}\right)_{2}\right]\left[\mathrm{Cu}(\mathrm{dac})_{2}\right]\left[\mathrm{B}_{7} \mathrm{O}_{9}(\mathrm{OH})_{5}\right]_{2} \cdot 4 \mathrm{H}_{2} \mathrm{O}$ [35] and has 8 dac amino ligand hydrogens atoms and 4 coordinated-water hydrogens per cation as potential H-bond donors. A diagram of the secondary coordination sphere around $\mathrm{Zn} 1$ of $\mathbf{3}$ is shown in Figure 6. There are two heptaborate(2-) anions within the secondary coordination shell around Zn1 and O29 is the heptaborate acceptor site from N1H1C. The coordinated $\mathrm{H}_{2} \mathrm{O}$ ligand (O1) forms a H-bond to the same heptaborate (O34) forming a $\mathrm{R}_{2}{ }^{2}(8)$ ring, which includes Zn1 within the ring system. The two (symmetery related) $\mathrm{O} 1$ atoms also receive donor H-bonds from two aqua ligands (O11) on neighbouring cations, which contain Zn2. The secondary coordination sphere around Zn2 also involves 3 out of the 4 dac amino H-atoms H-bonding to 4 heptaborate(2-) anions. The hetaborate(2-) anions also H-bond to one another via strong $\mathrm{R}_{2}^{2}(8)$ interactions similar to those found in $\mathbf{1}$ and in many pentaborate(1-) structures [16-19]. Details of all these H-bonding interactions and a diagram of the secondary coordination sphere around $\mathrm{Zn} 2$ are available in the Supplementary Information (Figure S5). Again, the combination of these cation-anion $\mathrm{H}$-bond interactions, together with the strong pairwise $\mathrm{R}_{2}{ }^{2}(8)$ anion-anion $\mathrm{H}$-bond interactions, are implicated in the preference of this system to self-assemble into a rarely observed heptaborate(2-) salt. 


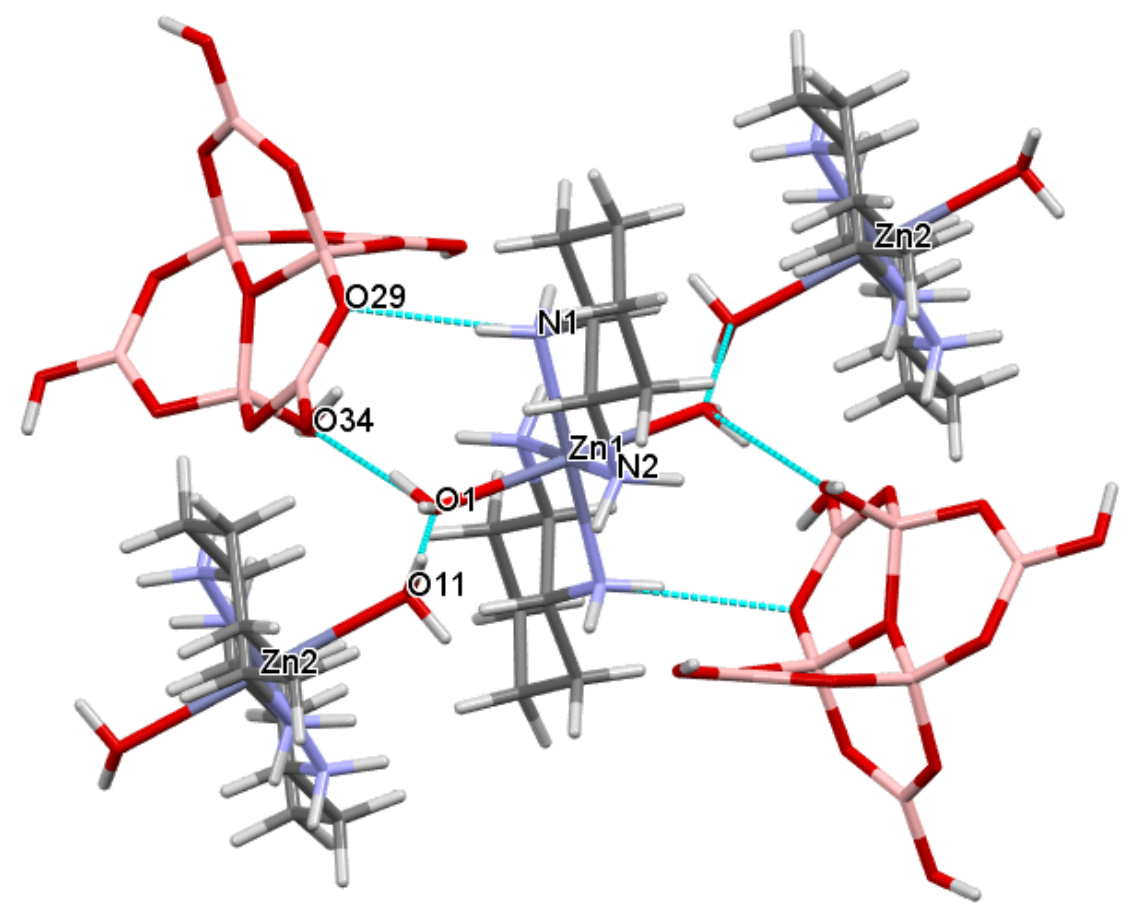

Figure 6. Secondary coordination shell around the Zn1 centre in 3.

Since the cation in compound $\mathbf{2}$ has no potential H-bond donor sites the cation must be influencing the observed polyborate architecture by other means. To a first approximation it is a relatively large, approximately spherical, cation (diameter of $\sim 11.5 \AA$ ) presenting hydrophobic $\mathrm{CH}$ bonds to the polyborate anions. This cation size is too large to fit comfortably within a possible pentaborate(1-) anion structure [22]. In addition to this steric issue, each cation in $\mathbf{2}$ interacts with 3 neighbouring cations in face-to-face $\pi$-stacking arrangements [58] forming layers of cations in a supramolecular 2-D hexagonal honeycomb 6,3-net topology (Figure 7). The $\pi$-stacking interactions are 3.5-3.8 $\AA$ (Supplementary Information Figure S6) and these distances are typical for such interactions [58]. The heptaborate(2-) anions are linked together into chains by strong reciprocal $\mathrm{R}_{2}{ }^{2}(8)$ interactions and the chains are crosslinked into 2-D planes by the interstitial $\mathrm{H}_{2} \mathrm{O}$ molecules (Figure 8). Detailed $\mathrm{H}$-bond interactions and a packing diagram of the structure is available in Supplementary Information (Figure S7). The combination of steric effects, cation-cation $\pi$-stacking interactions and anion-anion H-bond interactions all contribute to the energetics responsible for templating this unusual heptaborate(2-) structure. 


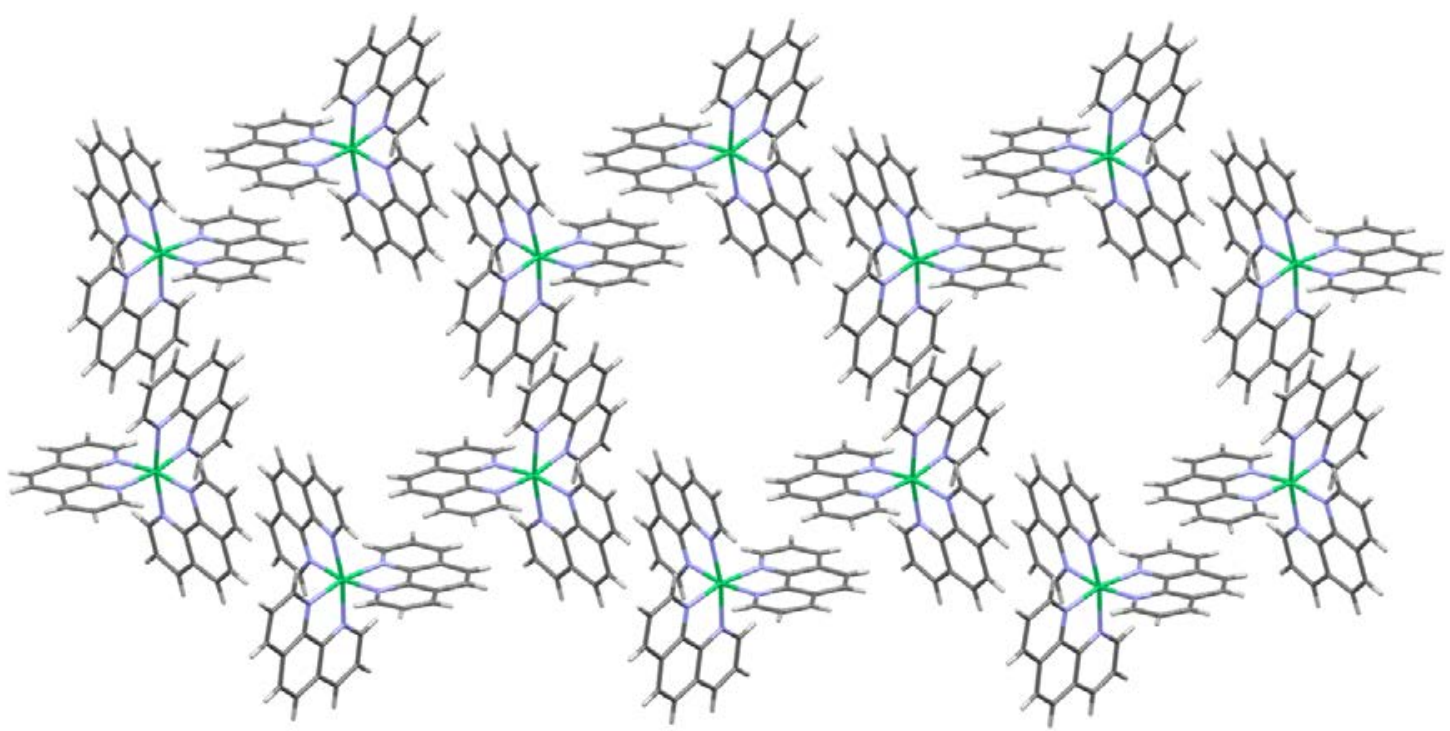

Figure 7. Honeycomb arrangement of the $\left[\mathrm{Ni}(\text { phen })_{3}\right]^{2+}$ cations in $\mathbf{2}$.

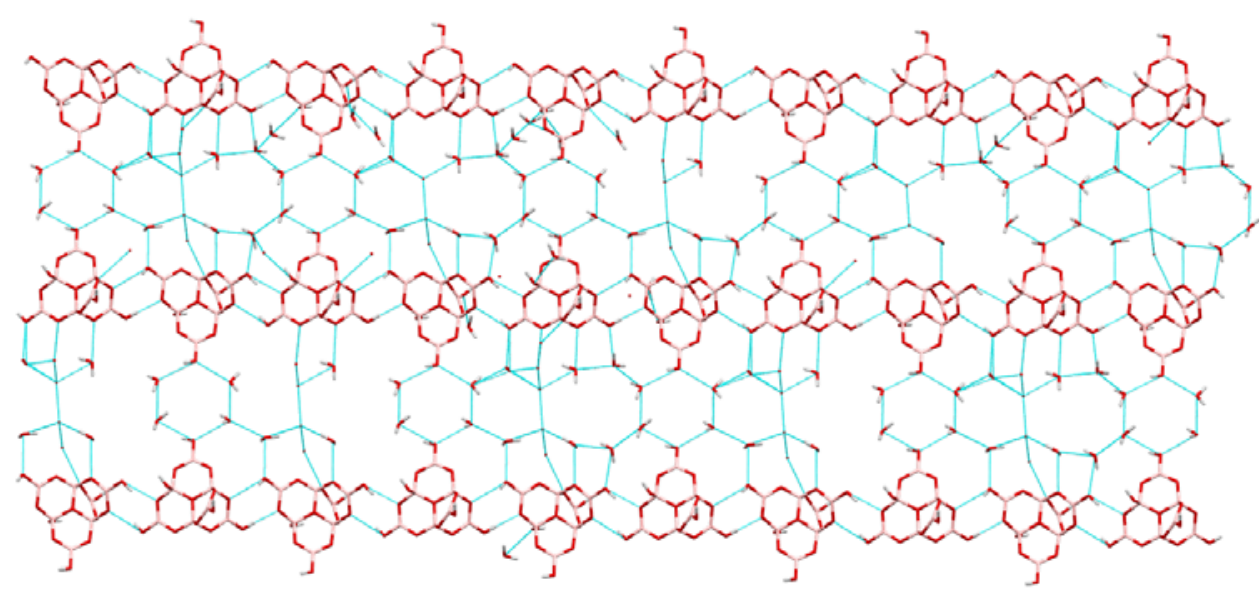

Figure 8. A plane in 2 comprised of chains of heptaborate(2-) anions linked by $\mathrm{R}_{2}{ }^{2}(8) \mathrm{H}$-bonding interations and cross-linked by $\mathrm{H}$-bonded $\mathrm{H}_{2} \mathrm{O}$ molecules.

\section{CONCLUSION}

Three new polyborate salts (1-3), containing the insular tetraborate(2-) and heptaborate(2-) anions, have been prepared by adopting a synthetic strategy with the aim of avoiding the synthesis of pentaborate(1) salts. The strategy involved the use of a highly-charged and potentially multi-H-bond donor cation, 
$\left[\mathrm{Co}\left(\mathrm{NH}_{3}\right)_{6}\right]^{3+}$, and two sterically demanding $2+$ cations $\left(\left[\mathrm{Ni}(\text { phen })_{3}\right]^{2+}\right.$ and $\left.\left[\mathrm{Zn}(\mathrm{dac})_{2}\left(\mathrm{H}_{2} \mathrm{O}\right)_{2}\right]^{2+}\right)$ to template their synthesis from a DCL of polyborate anions which coexist in alkaline aqueous solution. XRD diffraction studies confirm that multiple cation-anion H-bond interactions are present in $\mathbf{1}$ and $\mathbf{3}$. Compounds 1-3 all show extensive anion-anion $\mathrm{R}_{2}^{2}(8) \mathrm{H}$-bond interactions. These H-bond interactions are important in stabilizing their observed solid-state structures. Compounds $\mathbf{2}$ and $\mathbf{3}$ contain more sterically demanding cations and it is believed this also influences the templating energetics. Furthermore, $\mathbf{2}$ is unable to form H-bond interactions with the heptaborate(2-) anions but the structure is stabilized by cation-cation $\pi$-stacking interactions. This study further confirms that cation/anion $\mathrm{H}$ bonding, cationic charge, and steric effects all play important roles in these self-assembly processes.

\section{Acknowledgments}

We thank the EPSRC for the use of the NCS X-ray crystallographic service (Southampton)

\section{Supplementary materials}

Crystallographic data (including detailed H-bond data, and additional Figures) TGA plots, IR and NMR spectroscopic data, have been deposited as supplementary information. CCDC1939463, CCDC1939464, and CCDC1939465 also contain the crystallographic data for this paper. These data can be obtained free of charge from the Cambridge Crystallographic Data Centre via www.ccdc.cam.ac.uk/data request/cif.

\section{REFERENCES}

[1] J.D. Grice, P.C. Burns, F.C. Hawthorne, Borate minerals. II. A hierarchy of structures based upon the borate fundamental building block, Can. Miner. 37 (1999) 731-762.

[2] G. Heller, A survey of structural types of borates and polyborates, Top. Curr. Chem. 131 (1986) 3998.

[3] C.L. Christ, J.R. Clark, A crystal-chemical classification of borate structures with emphasis on hydrated borates, Phy. Chem. Miner. 2 (1977) 59-87.

[4] D.M. Schubert, R.A. Smith, M.Z. Visi, Studies of crystalline non-metal borates, Glass Technol. 44 (2003) 63-70.

[5] P.C. Burns, J.D. Grice, F.C. Hawthorne, Borate minerals. I. Polyhedral clusters and fundamental building blocks, Can. Miner. 33 (1995) 1131-1151.

[6] P. Becker, A contribution to borate crystal chemistry: rules for the occurence of polyborate anion types, Z. Kristallogr. 216 (2001) 523-533.

[7] M.A. Beckett, Recent advances in crystalline hydrated borates with non-metal or transition metal complex cations, Coord. Chem. Rev. 323 (2016) 2-14. 
[8] M.A. Silver, T.E. Albrecht-Schmitt, Evaluation of f-element borate chemistry, Coord Chem. Rev. 323 (2016) 36-51.

[9] A.P. Topnikova, E.L. Belokoneva, The structure and classification of complex borates, Russ. Chem. Rev. 88 (2019) 204-228.

[10] E.L. Belokoneva, Borate crystal chemistry in terms of extended OD theory: topology and symmetry analysis, Crystallogr. Rev, 11 (2005) 151-198.

[11] D.M. Schubert, Borates in industrial use, Struct. Bond. 105 (2003) 1-40.

[12] D.M. Schubert, Boron oxides, boric acid and borates, Kirk-Othmer Encyclopedia of Chemical Technology, fifth ed. J. Wiley Sons, NY, 2011, pp 1-68.

[13] P.T. Corbett, J. Leclaire, L. Vial, K.R. West, J.-L. Wietor, J.K.M. Sanders, S. Otto, Dynamic combinatorial chemistry, Chem. Rev. 106 (2006) 3652-3711.

[14] G. Salentine, High-field ${ }^{11}$ B NMR of alkali borate. Aqueous polyborate equilibria, Inorg. Chem. 22 (1983) 3920-3924.

[15] J.L. Anderson, E.M. Eyring, M.P. Whittaker, Temperature jump rate studies of polyborate formation in aqueous boric acid. J. Phys. Chem. 68 (1964) 1128-1132.

[16] M.Z. Visi, C.B. Knobler, J.J. Owen, M.I. Khan, D.M. Schubert, Structures of self-assembled nonmetal borates derived from $\alpha, \omega$-diaminoalkanes. Cryst. Growth Des. 6 (2006) 538-545.

[17] M. Wiebcke, C.C. Freyhardt, J Felsche, G. Engelhardt, Clathrates with three-dimensional host structures of hydrogen bonded pentaborate $\left[\mathrm{B}_{5} \mathrm{O}_{6}(\mathrm{OH})_{4}\right]^{-}$ions: pentaborates with the cations $\mathrm{NMe}_{4}{ }^{+}, \mathrm{NEt}_{4}{ }^{+}, \mathrm{NPhMe}_{3}{ }^{+}$and $\mathrm{pipH}^{+}$(pipH ${ }^{+}=$piperidinium). Z. Naturforsch. 48b (1993) 978-985.

[18] M.A. Beckett, C.C. Bland, P.N. Horton, M.B. Hursthouse, K.S. Varma, Supramolecular structures containing 'isolated' pentaborate anions and non-metal cations: Crystal structures of $\left[\mathrm{Me}_{3} \mathrm{NCH}_{2} \mathrm{CH}_{2} \mathrm{OH}\right]\left[\mathrm{B}_{5} \mathrm{O}_{6}(\mathrm{OH})_{4}\right]$ and [4-Mepy,4-MepyH] $\left[\mathrm{B}_{5} \mathrm{O}_{6}(\mathrm{OH})_{4}\right]$, J. Organomet. Chem. 692 (2007) 692, 2832-2838.

[19] M.A. Beckett, S.J. Coles, R.A. Davies, P.N. Horton, C.L. Jones, Pentaborate(1-) salts templated by substituted pyrrolidinium cations: synthesis, structural characterization and modelling of solid-state H-bond interactions by DFT calculations, Dalton Trans. 44 (2015) 7032-7040.

[20] M.A. Altahan, M.A. Beckett, S.J. Coles, P.N. Horton, A new polyborate anion, $\left[\mathrm{B}_{7} \mathrm{O}_{9}(\mathrm{OH})_{6}\right]^{3-}$ : selfassembly, XRD and thermal properties of $s$-fac-[Co(dien $\left.)_{2}\right]\left[\mathrm{B}_{7} \mathrm{O}_{9}(\mathrm{OH})_{6}\right] \cdot 9 \mathrm{H}_{2} \mathrm{O}$, Inorg. Chem. Commun. 59 (2015) 95-98.

[21] M.A. Altahan, M.A. Beckett, S.J. Coles, P.N. Horton, A new decaoxidooctaborate(2-) anion, $\left[\mathrm{B}_{8} \mathrm{O}_{10}(\mathrm{OH})_{6}\right]^{2-:}$ synthesis and characterization of $\left[\mathrm{Co}(\mathrm{en})_{3}\left[\mathrm{~B}_{5} \mathrm{O}_{6}(\mathrm{OH})_{4}\right]\left[\mathrm{B}_{8} \mathrm{O}_{10}(\mathrm{OH})_{6}\right] \cdot 5 \mathrm{H}_{2} \mathrm{O}\right.$ (en = 1,2-diaminoethane), Inorg. Chem. 54 (2015) 412-414. 
[22] M.A. Beckett, S.J. Coles, P.N. Horton, C.L. Jones, Polyborate anions partnered with large nonmetal cations: triborate (1-), pentaborate(1-) and heptaborate(2-) salts, Eur. J. Inorg. Chem. (2017) 45104518.

[23] J. Bjerrum, J.P. McReynolds, A.L. Oppegard, R.W. Parry, Hexamminecobalt(III) salts, Inorg. Synth. 2 (1946) 216-221.

[24] Crystal clear, Rigaku Corporation, The Woodlands, Texas, USA, (2008-2014).

[25] CrysAlisPro Software System, Rigaku Oxford Diffraction, Yarnton, Oxford UK (2019).

[26] O.V. Dolomanov, L.J. Bourhis, R.J. Gildea, J.A.K. Howard, H. Puschmann, Olex2: a complete structure solution, refinement and analysis programme, J. Appl. Cryst. 42 (2009) 339-341.

[27] G.M. Sheldrick, SHELXT - integrated space-group and crystal structure determination, Acta Cryst. A71 (2015) 3-8.

[28] G.M. Sheldrick, Crystal structure refinement with ShelXL, Acta Cryst. C71 (2015) 3-8.

[29] M.A. Beckett, P.N. Horton, M.B. Hursthouse, D.A. Knox, J.L. Timmis, Structural (XRD) and thermal (DSC, TGA) and BET analysis of materials derived from non-metal cation pentaborate salts, Dalton Trans. 39 (2010) 3944-3951.

[30] M.C. Etter, Encoding and decoding hydrogen-bond patterns of organic chemistry, Acc. Chem. Res. 23 (1990) 120-126.

[31] D.F. Evans, A new type of magnetic balance, J. Phys. E: Sci. Instrum. 7 (1974) 247-249.

[32] B.N. Figgis, J. Lewis, The magnetic properties of transition metal complexes, Progr. Inorg. Chem. 6 (1964) 37-240.

[33] J. Li, S. Xia, S. Gao, FT-IR and Raman spectroscopic study of hydrated borates, Spectrochim. Acta 376 (1995) 401-407.

[34] M.A. Beckett, P.N. Horton, M.B. Hursthouse, J.L. Timmis, K.S. Varma, Templated heptaborate and pentaborate salts of cyclo-alkylammonium cations: structural and thermal properties, Dalton Trans. 41 (2012) 4396-4403.

[35] M.A. Altahan, M.A. Beckett, S.J. Coles, P.N. Horton, Synthesis and characterization of polyborates templated by cationic copper(II) complexes: structural (XRD), spectroscopic, thermal (TGA/DSC) and magnetic properties, Polyhedron 135 (2017) 247-257.

[36] D.M. Schubert, F. Alam, M.Z. Visi, C.B. Knobler, Structural characterization and chemistry of an industrially important zinc borate, $\mathrm{Zn}\left[\mathrm{B}_{3} \mathrm{O}_{4}(\mathrm{OH})_{3}\right]$, Chem. Mater.15 (2003) 866-871.

[37] G.-M. Wang, Y.-Q. Sun, G.-Y. Yang, Synthesis and crystal structures of three new borates templated by transition-metal complexes in situ, J. Solid State Chem. 179 (2006) 1545-1553.

[38] Y. Yang, Y. Wang, J. Zhu, R.-B. Liu, J. Xu, C.-C. Meng, A new mixed ligand copper pentaborate with square-like, rectangular-like and ellipse-like channels formed via hydrogen-bonds, Inorg. Chim. Acta 376 (2011) 401-407. 
[39] Z.-H. Liu, J.-J. Zhang, W.-J. Zhang, Synthesis, crystal structure and vibrational spectroscopy of a novel mixed ligands $\mathrm{Ni}(\mathrm{II})$ pentaborate $\left[\mathrm{Ni}\left(\mathrm{C}_{4} \mathrm{H}_{10} \mathrm{~N}_{2}\right)\left(\mathrm{C}_{2} \mathrm{H}_{8} \mathrm{~N}_{2}\right)_{2}\right]\left[\mathrm{B}_{5} \mathrm{O}_{6}(\mathrm{OH})_{4}\right]_{2}$, Inorg. Chim. Acta 359 (2006) 519-524.

[40] M.A. Altahan, M.A. Beckett, S.J. Coles, P.N. Horton, Copper(2+) complexes of hydroxyoxidoborates. Synthesis and characterixation of two clusters containing the hexaborate(2) ligand: $\left[\mathrm{Cu}\left(\mathrm{NH}_{2} \mathrm{CH}_{2} \mathrm{CH}_{2} \mathrm{NEt}_{2}\right)\left\{\mathrm{B}_{6} \mathrm{O}_{7}(\mathrm{OH})_{6}\right\}\right] \cdot 5 \mathrm{H}_{2} \mathrm{O}$ and $\left[\mathrm{Cu}\left(\mathrm{NH}_{3}\right)_{2}\left\{\mathrm{~B}_{6} \mathrm{O}_{7}(\mathrm{OH})_{6}\right\}\right] \cdot 2 \mathrm{H}_{2} \mathrm{O}$, J. Clust. Sci. 30 (2019) 599-605.

[41] R.P. Sharma, R. Bala, R. Sharma, J.M. Salas, M. Quiros, Cationic cobaltammines as anion receptors: a convenient synthesis and the X-ray structure of hexaamminecobalt(III) chloride dichromate monohydrate, J. Coord. Chem. 58 (2005) 217-223.

[42] C.L. Christ, J.R. Clarke, A crystal-chemical classification of borate structures with emphasis on hydrated borates, Phys. Chem. Miner. 2 (1977) 59-87.

[43] G.J. Gainsford, T. Kemmitt, C. Higham, Redetermination of the borax structure from laboratory Xray data at $145 \mathrm{~K}$, Acta Cryst. E64 (2008) i24-225.

[44] L. Zheng, J. Zhang, Z. Liu, Chin. J. Chem. Synthesis, crystal structure and thermal behavior of $\left[\mathrm{Co}(\mathrm{en})_{3}\right]\left[\mathrm{B}_{4} \mathrm{O}_{5}(\mathrm{OH})_{4}\right] \mathrm{Cl} \cdot 3 \mathrm{H}_{2} \mathrm{O}$ and $\left[\mathrm{Ni}(\mathrm{en})_{3}\right]\left[\mathrm{B}_{5} \mathrm{O}_{6}(\mathrm{OH})_{4}\right]_{2} \cdot 2 \mathrm{H}_{2} \mathrm{O}, 27$ (2009) 494-500.

[45] D. Lin, X. You, L. Zhu, Chin. J. Chem. Synthesis, crystal structure and vibrational spectroscopy of $\mathrm{NH}_{4}\left[\mathrm{Co}\left(\mathrm{NH}_{3}\right)_{5}\left(\mathrm{H}_{2} \mathrm{O}\right)\right]\left[\mathrm{B}_{4} \mathrm{O}_{5}(\mathrm{OH})_{4}\right]_{2} .6 \mathrm{H}_{2} \mathrm{O}, 29$ (2011) 468-472.

[46] D. Lin, X. You, L. Zhu, A new organic-inorganic hybrid copper pentaborate with free boric acid group, Chin. J. Chem. 29 (2011) 463-467.

[47] C.-Y. Pan, G.-M. Wang, S.-T. Zheng, G.-Y. Yang, Cyclohexane-1,4-diammonium tetrahydroxotetraborate 2.5-hydrate, Acta Cryst. E63 (2007) o1207-o1209.

[48] G.-M. Wang, Y.-Q. Sun, G.-Y. Yang, Synthesis and crystal structures of two organically templated borates, J. Solid State Chem. 177 (2004) 4648-4654.

[49] M.A. Beckett, P.N. Horton, S.J. Coles, D.W. Martin, Synthesis and structural characterization of an unprecedented nonmetal cation polyborate salt containing two different "isolated" polyborate anions: $\left[\mathrm{H}_{2} \mathrm{en}\right]_{2}\left[\mathrm{~B}_{4} \mathrm{O}_{5}(\mathrm{OH})_{4}\right]\left[\mathrm{B}_{7} \mathrm{O}_{9}(\mathrm{OH})_{5}\right] \cdot 3 \mathrm{H}_{2} \mathrm{O}\left(\mathrm{en}=\mathrm{H}_{2} \mathrm{NCH}_{2} \mathrm{CH}_{2} \mathrm{NH}_{2}\right)$, Inorg. Chem. 50 (2011) 12215-12218.

[50] A. von Zelewsky, Stereochemistry of Coordination Compounds, John Wiley, Chichester, 1995.

[51] B. Zhang, L.-Z. Li, J. Li, Y.-C. Zhang, S.-H. Liu, Y.-L. Deng, [Ni(phen) $\left.)_{3}\right] \mathrm{Sn}_{3} \mathrm{Se}_{7} \cdot 1.5 \mathrm{H}_{2} \mathrm{O}$ : a new two-dimensional layered selenidostannate templated by $\left[\mathrm{Ni}(\mathrm{phen})_{3}\right]^{2+}$ complexes, Inorg. Chem. Commun. 106 (2019) 76-80.

[52] S.J. Archibald, Zinc in Comprehensive Coordination Chemisty II (2nd Ed), J.A. McCleverty, T.J. Mayer Eds, Elsevier, Amsterdam, The Netherlands, 6 (2003) 1147-1251.

[53] D.M. Schubert, M.Z. Visi, S. Khan, C.B. Knobler, Synthesis and structure of a new heptaborate oxoanion isomer: $\mathrm{B}_{7} \mathrm{O}_{9}(\mathrm{OH})_{5}{ }^{2-}$, Inorg. Chem. 47 (2008) 4740-4745. 
[54] D.A. Kose, O. Yurdakul, O. Sahin, Z. Ozturk, The new metal complex templated polyoxoborate(s) (POB(s)) structures. Synthesis, structural characterization and hydrogen storage capacities, J. Mol. Struct. 1134 (2017) 806-813.

[55] M.A. Beckett, S.J. Coles, M.E. Light, L. Fischer, B.M. Stiefvater-Thomas, K.S. Varma, Synthesis and X-ray characterization of the organotriboroxinate salts $\left[\mathrm{Me}_{3} \mathrm{NCH}_{2} \mathrm{CH}_{2} \mathrm{OH}\right]\left[\mathrm{Ph}_{4} \mathrm{~B}_{3} \mathrm{O}_{3}\right]$ and $\left[\mathrm{NEt}_{3} \mathrm{H}\right]\left[\mathrm{Ph}_{3} \mathrm{~B}_{3} \mathrm{O}_{3}(\mathrm{OH})\right]$ and the $\mathrm{X}$-ray structure of the triarylboroxine (4- $\left.\mathrm{MeC}_{6} \mathrm{H}_{4}\right)_{3} \mathrm{~B}_{3} \mathrm{O}_{3}$, Polyhedron 25 (2006) 1011-1016.

[56] M.A. Beckett, E.L. Bennett, P.N. Horton, M.B. Hursthouse, Tetraphenylboroxinate(1-) salts of monoborate cations: Synthesis and single crystal X-ray structures of $\left[\mathrm{Ph}_{2} \mathrm{~B}\left\{\mathrm{OCH}_{2} \mathrm{CH}_{2} \mathrm{~N}(\mathrm{Me})\left(\mathrm{CH}_{2}\right)_{\mathrm{n}}\right\}_{2}\right]\left[\mathrm{Ph}_{3} \mathrm{~B}_{3} \mathrm{O}_{3}\right](\mathrm{n}=4,5)$, J. Organomet. Chem. 695 (2010) 10801083.

[57] W. Kliegel, H.-W. Motzkus, S.J. Rettig, J. Trotter, Structural studies of organoboron compounds. XXII. Preparation and crystal and molecular structure of tetramethylammonium-2,4,6,6tetraphenyl-1,3,5-trioxa-2,4-dibora-6-boratacyclohexane, Can. J. Chem. 63 (1985) 3516-3520.

[58] G.R. Desiraju, A. Gavezzotti, From molecular to crystal structure; polynuclear aromatic hydrocarbons, J. Chem. Soc., Chem. Commun. (1989) 621-623. 